Cornelius Holtorf

\title{
Meta-stories of archaeology
}

(accepted for publication in World Archaeology Issue 3, 2010)

\begin{abstract}
I argue that archaeologists contribute most to the contemporary Experience Society when they tell stories. Such stories well-told may be either about what happened in the past or about how archaeology proceeds. Far more significant are, however, the meta-stories of archaeology. These are defined as stories of archaeology in which contemporary audiences themselves feature as characters, engulfed in a plot about archaeology or the past that gives meaning and perspective to their present-day lives. Such meta-stories may draw on metaphorical meanings that resonate in the practices of professional archaeology. In this paper, however, the emphasis is put on another type of meta-stories that explore, in relation to the past, what it means to be human, who we are as members of a particular human group, and how we might be living under different circumstances. I argue that archaeologists need to get better at understanding and critically appreciating the overarching meta-stories they evoke. For archaeology matters when its meta-stories matter.
\end{abstract}

Keywords: cultural heritage, Experience Society, story-telling, meta-stories, humanity, collective identities, alternative ways of life

\section{Stories and meta-stories in archaeology}

When a stranger finds out that you are an archaeologist, the set of questions you will be asked is fairly predictable: Where do you dig? Have you been to Egypt? Which period do you specialise in? What was the best find you ever made? Many archaeologists are flattered by the interest and will do their best to answer as accurately as possible, while at the same time very gently putting right a few common stereotypes and misconceptions. But arguably this ritualised questioning aims at something other than what it literally asks for. Rather than giving truthful answers to specific questions, the task demanded from the archaeologists is in fact to tell some stories. By stories (or narratives) I mean an account of one or more characters acting out plots in a sequence of events that contain a distinctive beginning, middle, and end (cf. Pluciennik 1999: 654-5).

Throughout popular culture, archaeology is often seen as the stuff of exciting stories rather than as a tool for getting answers to specific questions about the past (Holtorf 2007). This is not necessarily a problem but indeed an opportunity in a society that has been described in terms of an Experience Society, Experience Economy and Dream Society (Schulze 1992; Pine and Gilmore 1999; Jensen 1999). According to these analyses, social and economic dynamics in highly developed "Western" societies do no longer revolve around products or services but around stories, experiences and dreams that engage customers in various ways (Figure 1). Archaeology as the provider of stories can thus play a particularly significant role in $21 \mathrm{st}$ century society. Arguably, archaeology and archaeological heritage are not only modes of cultural production (Pearson and Shanks 2001), but effectively they have become creative 
industries providing stories in demand. According to American archaeologist and writer Brian Fagan (2002: 254), professional archaeologists have indeed become "performers on a public stage" who work as "sophisticated storytellers".

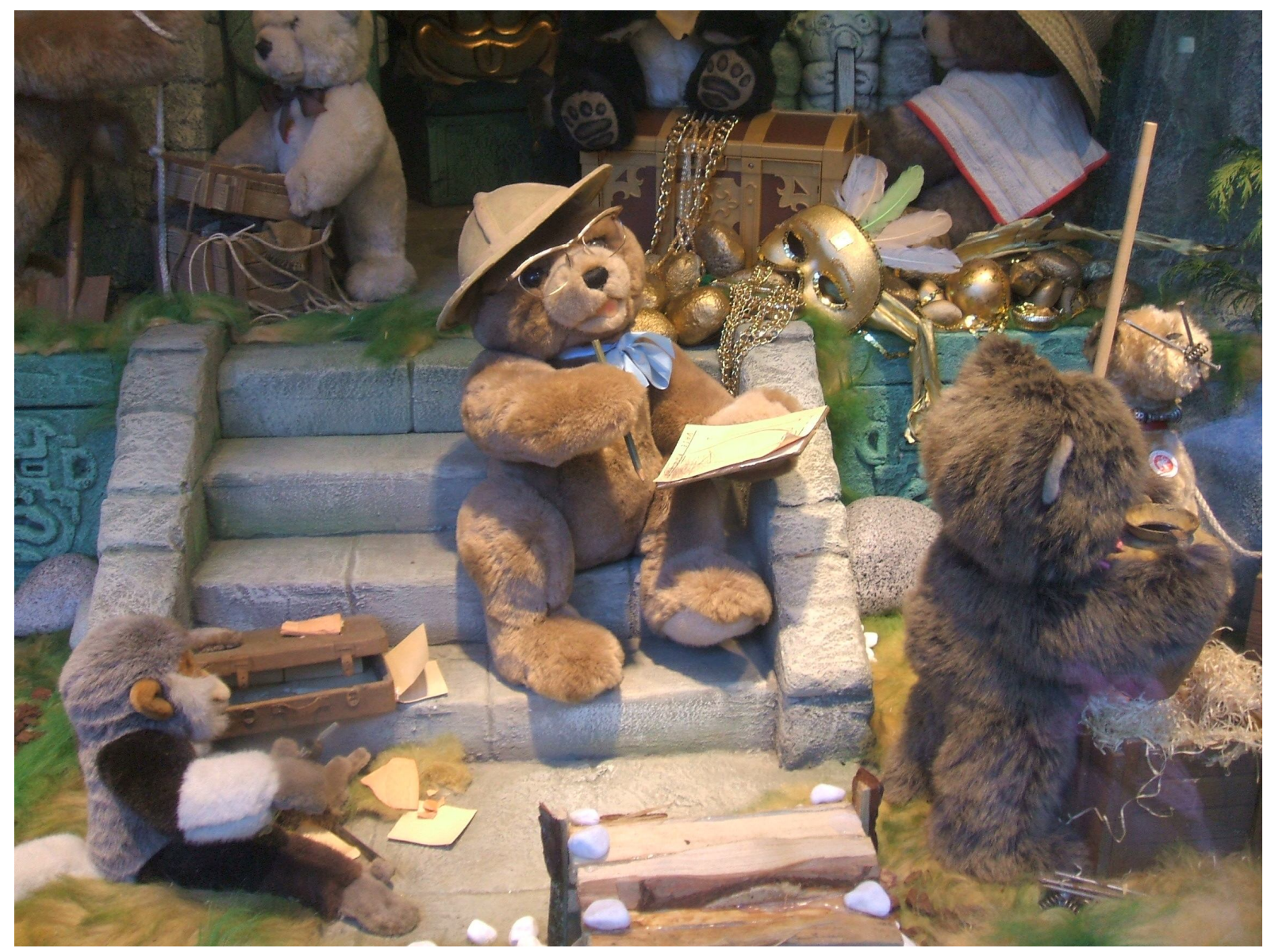

Figure 1: Archaeological story-telling in the shop window of the German warehouse Galeria Kaufhof in Cologne. Photograph: Geoff Carver 2006, reproduced with permission.

Interpreting archaeology as story-telling is not a new idea. Taking inspiration from historian Hayden White's (1973) analysis of historian's texts as narratives with tropes and plots, the journalist and archaeologist Mark Pluciennik presented in 1999 a general discussion of the roles and possibilities of story-telling in archaeology. In particular he analyzed the narratives in various theories of the Mesolithic-Neolithic transition in Europe (see also Rudebeck 1996). One of his examples is science writer Misia Landau's (1991) analysis of narratives of human evolution. She found that early twentieth century theories of human evolution reflected in fact varieties of a basic narrative structure where certain elements were recombined in order to tell different stories. Similar in some respects, anthropologist John Terrell (1990) had argued that storytelling in science is not just a way of communicating complex ideas but a mode of exploration and a kind of model-making that allows us to create comparative frameworks for evaluating different theories. For archaeologist Janet Spector (1993), on the other hand, storytelling was a tool for making sense of the past. In her analysis of "what this awl means", she demonstrated how telling stories of possible past realities might help us to connect with the thoughts and feelings of the human beings we are actually talking about. A similar position was advocated by prehistorian Mark Edmonds in telling narratives about Neolithic Britain 
(1999). In a special issue of the academic journal Historical Archaeology on "Archaeologists as Storytellers" (Praetzellis and Praetzellis 1998), various authors celebrated the archaeological imagination by presenting short stories, diary entries, dialogues, and even a play, all based on specific excavation results. Performance artist Mike Pearson and archaeologist Michael Shanks together explored the converging complexities of story-telling in archaeology and theatrical performance (2001). Others felt a desire to tell stories about the academic discourse of archaeology and current trends in archaeological theory (e.g. Flannery 1982; Tilley 1990). Adrian Praetzellis even published two textbooks on archaeological theory and methodology in the form of mystery stories (e.g. Praetzellis 2000).

These examples attest to the potential of archaeological stories to move people and interest them in a particular aspect of (studying) the past, whether they are laypeople or highly educated specialists. Advocating archaeology as story-telling does not mean to 'dumb-down' or 'vulgarize' academic research by emphasizing the lowest common denominator of interest among a mass audience. Indeed, the stories archaeology tells can be complex and their messages may not always be popular or delightful. Archaeologists who strive to tell good stories thus do not necessarily 'prostitute' or 'sell out' their discipline in order to gain that extra bit of attention. Instead, storytelling can be considered as one way in which the academic field of archaeology can fulfil an important function in society. In order to demonstrate this, I need to move beyond re-establishing that archaeological research results and accounts of its methods and ways of reasoning can profitably be told in story format. I also must do more than merely repeat the truism that stories can widely attract interest in archaeology, as exemplified by the numerous archaeological novels and movies, TV documentaries and news items, re-enactments and computer games that flourish in popular culture.

I therefore wish, in this paper, to take one step back from the kinds of stories that archaeologists and others may tell explicitly. Instead, I will be looking at the underlying stories that frame any archaeology we conduct and make it significant to contemporary society (see also Silberman 1995; Högberg 2006). These underlying stories may be described as meta-stories of archaeology. In meta-stories, members of contemporary audiences feature themselves as characters, engulfed in a plot about archaeology or the past that gives meaning and perspective to their present-day lives. Meta-stories of archaeology must be distinguished from meta-narratives of the past, although both concepts may occasionally overlap. The latter provide an overarching view of changes and continuities that are visible in the past, for example by portraying cultural evolution as progress or as decline, or by suggesting certain unchanging traits of human behaviour (Aronsson 2004: 79-81; Holtorf 2005: 109-111). The former, on the other hand, make archaeological practices, objects, and research results meaningful in an existential, social and political context in the present.

\section{A short survey of meta-stories of archaeology}

The general kind of stories archaeology tells best are not subject to frequent changes and have been around for a while (Pallottino 1968; Holtorf 2005, 2007). Ever since the nineteenth century, if not before, conducting fieldwork in exotic places, discovering wonderful treasures, investigating the mysteries of ancient civilisations, reconstructing past ways of life after painstaking detective work, and searching for one's ancestors and collective origins have been the stuff out of which archaeological stories are made. Such stories are often highly entertaining for mass audiences - the most recent Indiana Jones film has been grossing more than US \$ 786 million worldwide, and the British TV Series Time Team has been running 
since 1994 attracting regularly millions of viewers in many countries. The reason for the currency of archaeological stories lies, however, on a different level. These stories have a distinctive archaeo-appeal which is in parts celebrating the magic of practicing archaeology and in parts imagining what the past was like. The former I explored in detail elsewhere (Holtorf 2007), pointing to the metaphorical meaning of heroes overcoming adversity, solving mysteries through meticulous analyses and managing scarce resources responsibly. Such meta-stories resonate frequently in the actual practices of professional archaeology.

In this paper, however, the emphasis is put on a second type of meta-stories that explore some profound issues in relation to accounts of the past. In particular three such meta-stories connect archaeological research about the past with matters of considerable social significance. They address

(a) what it means to be human,

(b) who we are as members of a particular human group, and

(c) how we might be living under different circumstances.

In stories about the archaeological past, I argue, it is not the past as such which attracts interest and gains social significance but rather important issues that an engagement with the past bring up (see also Aronsson 2004). I will now discuss each of these three meta-stories of archaeology in turn.

\section{Meta-stories about being human}

Among the most profound stories humans tell each other are those about the very meaning of being human. In terms of archaeology, they appear in two main forms. One concerns human origins where various hominan species play out plots of increasingly becoming human in physical, behavioural, social, and cultural ways. The question at what point in a continuous line of descent humans can be distinguished from non-humans is not a question of palaeoanthropology or archaeology but of philosophy. The question what it means to be human cannot be answered by scientific analysis. All human origin research is ultimately an engagement with human concepts of humankind (Fernández-Armesto 2004). This insight is nowhere better confirmed than by studying the iconography of human origins (Figure 2). Ever since the Medieval period, depictions of human ancestors - from Adam and Eve to Australopithecus africanus - have been reflecting changing understandings of human essence affecting everything from skin colour and amount of body hair to tool use, gender roles, cultural significance and a special glance in the eyes (Moser 1998). It is thus not surprising that the Maropeng Visitor Centre at the Cradle of Humankind World Heritage Site in South Africa features an exhibition that explicitly explores what it means to be human. The topics addressed include bipedalism, a mixed diet, a large brain, fabricated stone tools, control and use of fire, a complex language and creativity (1). Reflecting on each of these topics that all are subject of extensive research by archaeologists, palaeoanthropologists and others means to relate scientific evidence and analysis directly to ourselves as human beings. Famous discoveries like "Lucy" are not only meaningful in relation to finds of other human ancestors that lived millions of years ago but also in relation to each of us today who may share some of her genes, anatomy, and behaviour. This perspective places contemporary audiences as characters inside the story of human evolution. 


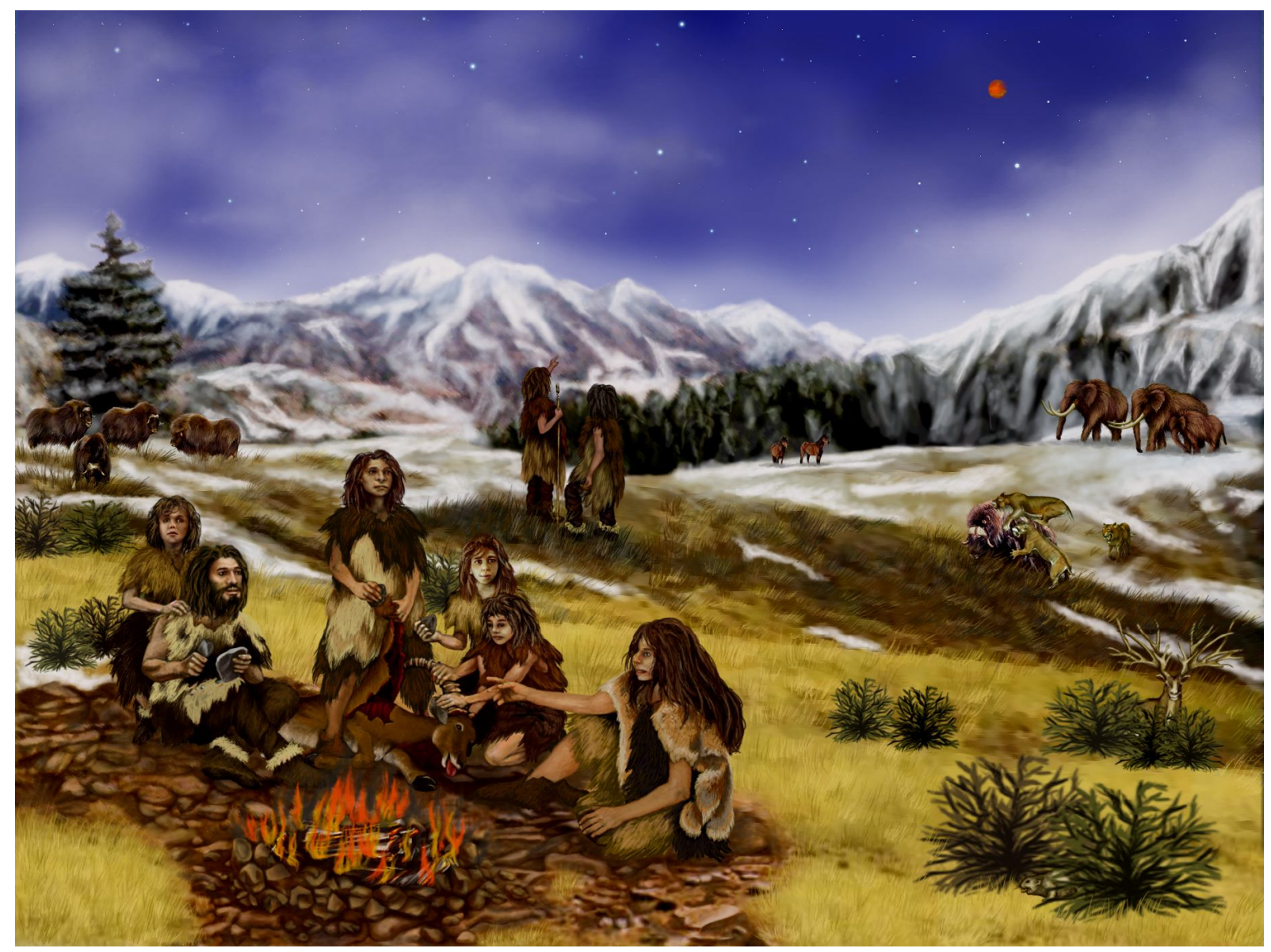

Figure 2: What it means to be human, according to an artist's rendition of Neanderthal life on Earth approximately 60,000 years ago. Image: Courtesy NASA/JPL-Caltech.

A second form in which archaeology tells meta-stories about being human is more poetic. Confronting audiences with sites or objects evoking death, decay, and forgetting provokes existential reflections. For example, looking at a skeleton people will contemplate that their own physical remains, too, might one day be inspected like this and that nobody might then remember them as living persons, let alone their names. Studies in contemporary archaeology can have a similar effect. A good example is the car cemetery at Kyrkö Mosse near Tingsryd in southern Sweden (Burström 2009). Numerous decaying wrecks representing much of 20th century automobile history were spread out along an old road running next to the modern one. By looking at these wrecks, many visitors become characters in a plot seeing the story of their own lives in front of them. They remember key events or periods in their lives associated with similar models and the status these cars once lent their owners. Seeing these wrecks now reminds them of the passage of time and that neither material possessions nor human individuals are forever. Intriguingly, a large number of people objected to the planned removal of the wrecks at Kyrkö Mosse when the authorities considered them to be environmental hazards. The popularity of the decaying site led eventually to its protection as a site of cultural significance and 20th century heritage. A car cemetery of wrecks in the woods may not be the classic heritage site but its poetry evidently tells a moving story about what it means to be human. 
Meta-stories about collective belonging

Probably the most common stories archaeologists tell about the past are in one way or another linked to collective human identities, i.e. pasts that are linked to a particular group of people in the present. The most inclusive group is that of all humans taken together. Meta-stories about being human, which I already discussed, are also always meta-stories about what all humans share with each other. By the same token, UNESCO World Heritage Sites represent the shared heritage of humankind. Any world heritage site automatically evokes the historical accomplishments of the human species around the globe. Modern visitors thus become characters in a meta-story describing a much larger collective group and its plot-like trajectory over time.

More exclusive are meta-stories about national pasts which are commonly linked to national histories (Silberman 1995). Indeed, archaeology and the modern nation-states have been developing parallel and in close interrelation to each other since the 19th century. The young nation-states were keen to establish for their citizens a common sense of belonging by telling stories of a common origin and a shared history. The burgeoning field of archaeology benefitted enormously from the establishment of national museums, national research institutions, and national legislation for archaeological sites and artefacts. Stories about national citizenship and the collective national past are still very firmly connected to each other. As a German citizen I am widely considered to be a member of the same group of people that started two World Wars, although I was born after both had ended many years previously and have not been living in Germany for nearly two decades. Vice versa, in order to become a Danish national, for example, applicants must, among other criteria, pass a special citizenship test by correctly answering at least thirty-two out of forty questions about Danish history, culture and society (Holtorf 2009b: 677).

On the regional and sometimes local level too, archaeological stories are used to express a sense of collective belonging. Such meta-stories of group identity are usually told by the inhabitants themselves, either to each other or to their guests and visitors. Similarly, members of a given social class or members of a certain family may express who they collectively are by telling stories about the past that create a plot in which they locate themselves as characters. For example, members of the educated middle classes may tell meta-stories about their own collective identity by conversing about visits of archaeological sites or exchanging knowledge and insight about historical events and processes, which reaffirm the values shared between them. In the literature they consult, particularly symbolic sites are conveniently marked as "must sees" on the tourist trail, thus facilitating their appropriate reception. 


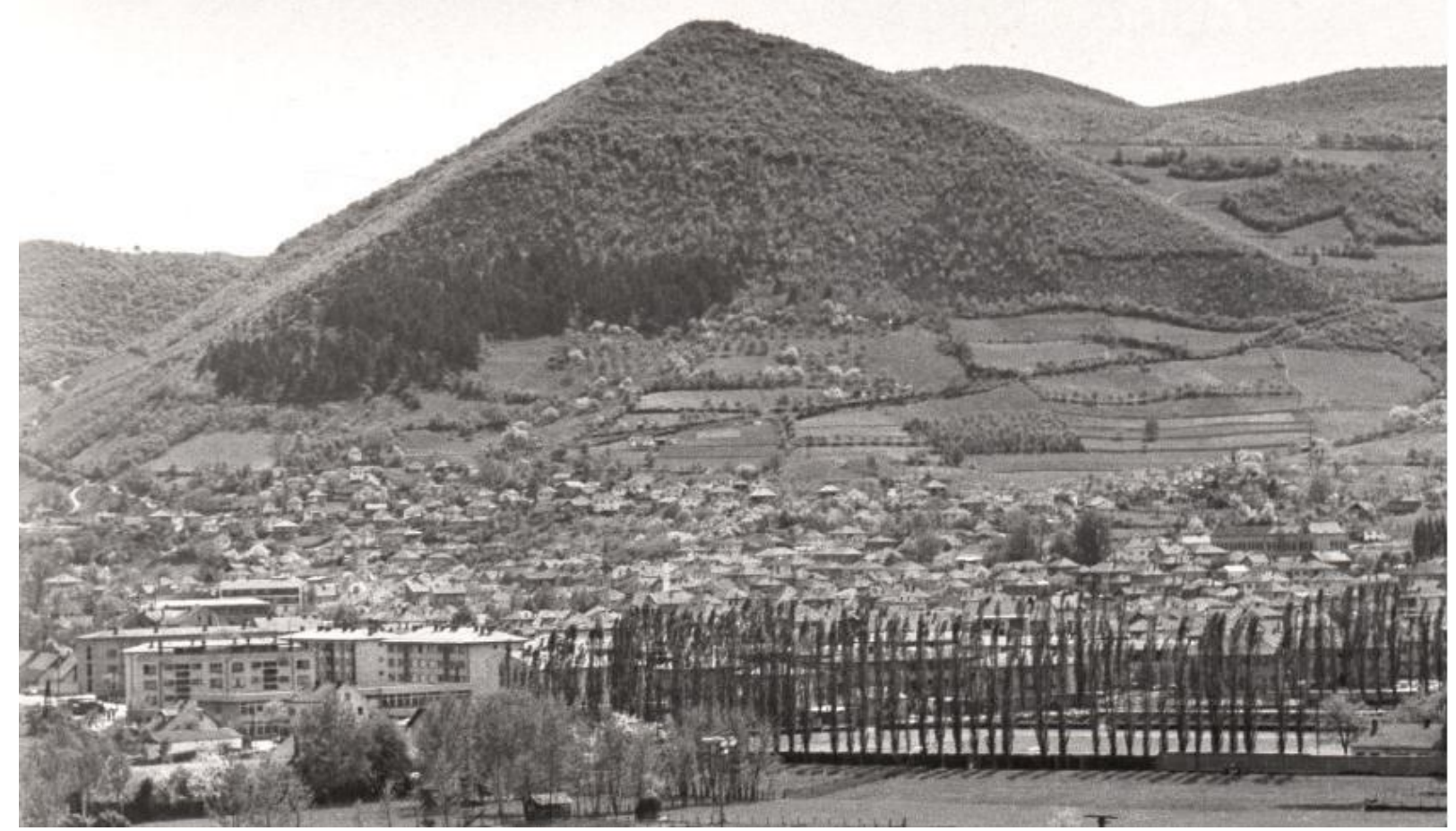

Figure 3: A Bosnian pyramid that has come to signify Bosnian collective identity.

Reproduced with a LGPL license from Wikipedia Commons:

http://en.wikipedia.org/wiki/File:1973_Visoko.jpg (detail)

An interesting contemporary case are the so-called Bosnian pyramids in Visoko near Sarajeyo (Pruitt 2009). Several mountains are claimed to be previously unknown pyramids of a lost civilization dating to as early as $12,000 \mathrm{BC}$ (Figure 3 ). The story about a newly discovered Bosnian past featuring huge pyramids that archaeological excavations are gradually revealing is uplifting for some, depressing for others, and amazingly entertaining for others again. Caught up in assessing the details of the story, archaeologists can easily miss the more significant dimension of the meta-story being told. Characteristic is the following statement from the pyramid promoters' own email newsletter (26 March 2010): "The discovery of the Bosnian pyramids launched Bosnia onto the world archaeological map as one of the cradles of civilisation... The largest pyramids, and potentially the oldest in the word, have been discovered, the highest quality ancient concrete and one of the largest underground networks of tunnels and spaces with multi-toned ceramic sculptures." The pyramids and its superlative archaeology thus serve to illustrate a glorious Bosnian heritage. They talk about a specific collective identity and sense of belonging firmly associated with ethnic nationalism (cf. Silberman 1995). Part of the controversy about the status of the pyramids can be attributed to worries about the nature and impact of that collective identity which appears to be reinforcing national pride in an unstable region that has recently witnessed war and ethnic cleansing.

As these examples demonstrate, cultural heritage is valued because it allows people to tell meta-stories that express a sense of collectively belonging to a certain community (see also Högberg 2006). Often stories about heritage and the past may be of considerable complexity, combining meta-stories about various different collective identities in one and the same account. At the same time, it is almost irrelevant precisely what kind of heritage and past is shared or how limited our knowledge about that heritage and its past may be. Even horrible 
historic events, such as those associated with Nazism, and even very limited knowledge about distant hominan species during the Pliocene are sufficient for telling stories that evoke distinct collective identities. What is more, even sites that may not be archaeological at all can successfully evoke meta-stories of archaeology. The archaeologist Tera Pruitt argued rightly that the imagined Bosnian pyramids have become important economic and social assets that attract tourists to a poor region of Europe so that they might actually be worth more to society than the heritage officially acknowledged by the country's own archaeologists (Pruitt 2009: 69). Meta-stories of archaeology can thus require us to delineate archaeological phenomena in ways that are at variance with academic conventions.

What matters is not so much the scientific accuracy, empirical richness or agreeable content of the story but that, as characters, we are caught in the plot of the meta-story behind it.

\section{Meta-stories about alternative ways of life}

A final category of meta-stories about archaeology is about alternative ways of life. Presentations of everyday life in the past whether in historical novels, TV documentaries or museum exhibitions fascinate because of an affective link that connects humans across all historical and indeed pre-historical periods, inviting not only sympathy but also empathy between fellow human beings - with important lessons to be learned for ourselves.

One of the goals of heritage interpretation has long been to re-create the past in the present in such a realistic way that it conveyed "the notion to the visitor that the ancients who lived here might come back this very night" (Tilden 2007: 102). In recent years, downright time travel experiences have become popular among contemporary audiences: from first-person interpretation, living history, historical role play and re-enactment, to historical docu-soaps, computer-generated historical movie scenes and interactive virtual realities (Holtorf 2010). What is shared between these genres is not only that they all tell stories about another time period but also that they offer their audiences an opportunity to identify with human ways of life in another age. Accounts and to some extent experiences of life in the past effectively invite people to reflect upon their own lives, scrutinising among others their values and priorities.

Such reflections are often carried out in a nostalgic frame of mind in which the past is admired for something now lost. But they can equally well be driven by hopes for future progress replacing past misery, or by a desire to be reassured about a timeless status quo. You may look for reassurance about living as you do, you may wish to improve on the past, or you may aspire to (re-)gain something valuable that once existed. Either way, a visit to the past can provide perspectives that contribute to refining present ways of life.

Archaeologically informed accounts of the Celtic Iron Age, for example, have inspired a considerable part of esoteric knowledge, New Age thought and Neo-pagan religions.

Although scholars are aware of numerous gaps in the evidence and the unreliability of written sources, many others do not hesitate to model some of their ideals and principles on perceived realities contained in stories about the Celtic past. This goes far beyond an admiration of a "Celtic" art-style or the construction of a "Celtic" identity by communities in Brittany, Wales, or Ireland and includes even spiritual guidance and political inspiration (Winkler 2006). The British scholar of religions Marion Bowman (1993: 154-5) reasoned in this context that "[a]t a time when many people are alarmed at the state of the environment and disillusioned with conventional religion, the Celts (...) are now seen as less tainted, as repositories of a spirituality that has elsewhere been lost." Celtic Druids have even been taken to be the 
inheritors of the Ancient Wisdom that once inhabited the mythical sunken city of Atlantis (Ashe 1992: 30, 81)! It thus becomes evident how an archaeological story that on one level describes aspects of a past reality may on another level offer utopian inspiration for an alternative way of life in the present.

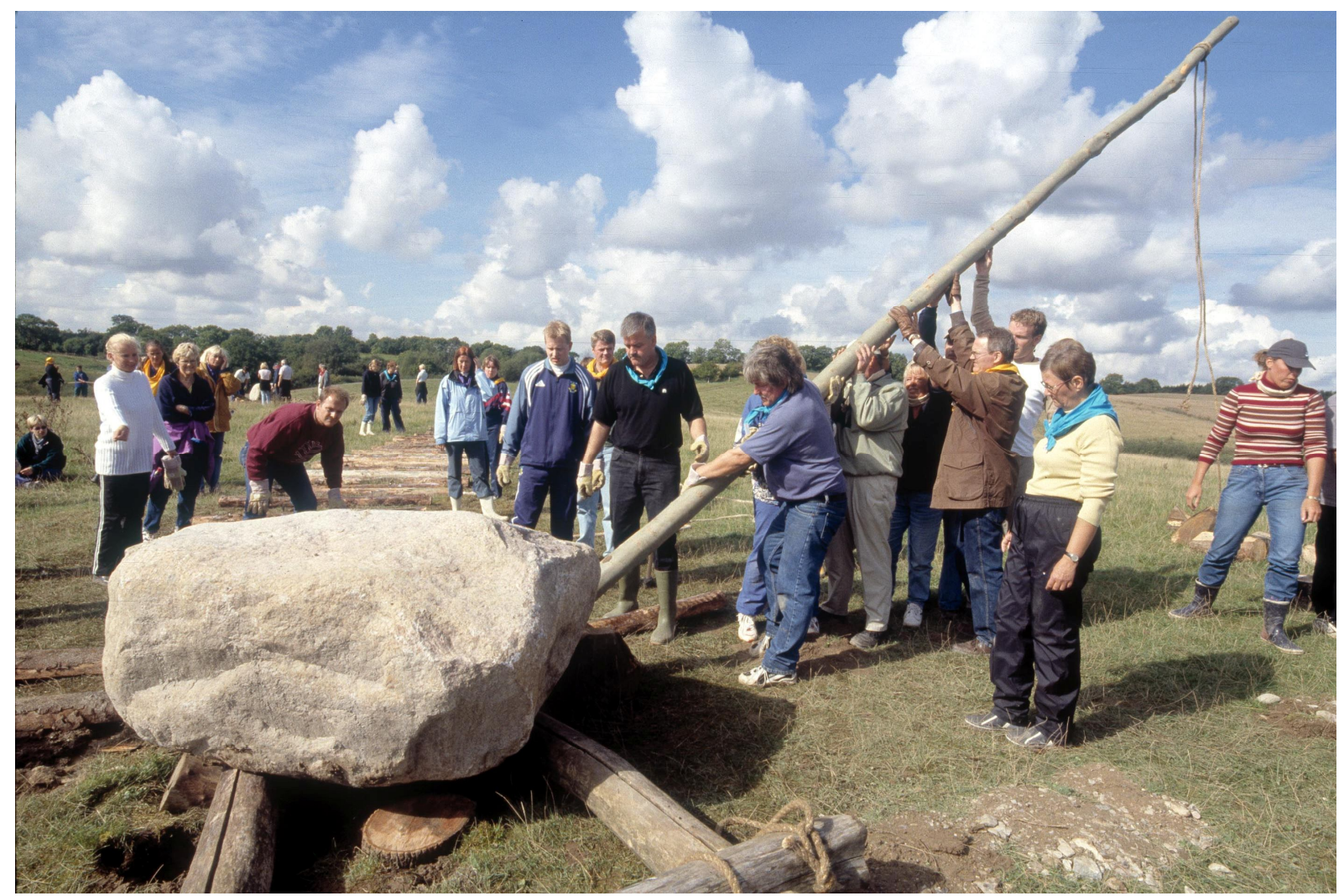

Figure 4: Moving a boulder in the prehistoric way can improve the present. Photograph: Sagnlandet Lejre, Centre for Historical-Archaeological Research and Communication, Denmark. Reproduced with permission.

Present-day ways of life might even in other ways be improved upon by recourse to the past. The archaeological open-air museum Sagnlandet Lejre in Denmark offers team-building activities in which groups of employees can re-enact activities of the past in order to improve on how they co-operate as a team. One such activity is moving a large boulder in the way the Neolithic megalith builders might have done (Figure 4). At face-value the story of moving a stone may be simple, involving some tools and some skills. But there is an explicit meta-story here in which the participants learn to solve a seemingly insurmountable task through a collective effort, thus improving their working relationships with each other:

"At first it seems like a quite impossible task - to move a stone which reaches your waist and is oblivious of your existence. In the end, the stone can be moved through a combination of co-operation, understanding, exchange of knowledge, communication and common sense. (...) And remember - not only faith can move mountains teamwork can also do the trick!" (2)

The confrontation with an exotic task of the past causes each individual to reconsider his or her role in the collective today, prompting an improved way of co-operating with each other. Becoming Stone Age builders for a day thus makes these groups more successful as teams in the present. 


\section{Conclusion: the significance of meta-stories of archaeology}

Some archaeologists may consider the proliferation of creative archaeological story-telling at best as a way of attracting goodwill for real archaeology and at worst as a distraction from archaeology's proper tasks of providing a critical voice in society and educating all those who want to know about the past. But telling stories and meta-stories about archaeology or the past can also be seen as a way of making a real and widely appreciated contribution to very many peoples' lives. As popular culture aptly demonstrates such stories do not only entertain large audiences but also connect with some of their most common fantasies, needs and desires (Holtorf 2007, 2009a). Meta-stories of archaeology benefit society by making people reflect upon what it means to be human and what they share with others in the social groups to which they belong. By presenting alternative ways of life in the past archaeology can also put our own realities into perspective and provide inspiration for the present. Indeed, the very persona of the archaeologist is known to serve as a role-model for some. Archaeological story-telling is thus an opportunity for archaeology to fulfil itself in contemporary society by directly improving the quality of peoples' lives, providing meaning, stimulation and guidance. The fact that archaeology is not the only way in which these benefits may be achieved does not take anything away from its potential.

There are excellent reasons why archaeologists need to conduct critical analyses of the stereotypes existing about both archaeology and the past. In some regions of the world, archaeology and archaeological heritage may, for instance, be contributing to creating an atmosphere in which war and ethnic cleansing are thinkable rather than unthinkable choices of human action. It should be self-evident that archaeologists need to evaluate carefully the social consequences of their actions, including those of the stories they tell (or invite others to tell) and of the meta-stories they evoke. Yet for all due caution archaeologists still need to serve their fellow citizens. In a nutshell, I have been arguing here that archaeology's social value lies first and foremost in well-told discovery stories that are appreciated by many, while at the same time providing meta-stories that are valuable both to society and to the individuals making up society. A critical perspective will always have to evaluate archaeology's complete impact on society and must thus also take into account the overall value of the stories and meta-stories that archaeology is contributing to society. The quality of archaeological stories is in part what its audience perceives it to be.

Many of the historical details that make up the stories and meta-stories of archaeology are necessarily fictitious. In fact, neither the appreciation of archaeological stories nor the impact of the meta-stories of archaeology depends on the degree to which their content corresponds to how it once "really" was or might have been. The stories do not need to be true in a strict scientific sense for their benefits to take effect. What is more, many audiences are not actually after the truthfulness of all elements of archaeological stories but rather after the larger benefits these stories and the meta-stories of archaeology provide with them, for example by giving meaning and perspective to their lives. This becomes clear when similar benefits are achieved by entirely fictitious creations as they are common in the visual arts. For example, during the 1970s the American artist Charles Simonds created hundreds of ruined dwellings of the imaginary Little People, both in New York City and beyond (Museum of Contemporary Art 1981). These are tiny structures made of clay bricks and built into the gaps of the modern city: gutters, window ledges, crevices in walls, etc. Whereas on one level, these ephemeral miniatures tell stories about the past lives of their invented builders and therefore do not reflect any historical reality at all, on another level they tell significant meta-stories. Passing 
audiences are inspired to reflect upon their lives in the community and built environment which apparently they once have been sharing with the Little People. What else do they seem to have in common with this lost civilization? How will their own culture end one day? What will remain of it, both physically and in people's memories? Could they take action to influence this trajectory and improve their fate?

In sum, if we are wondering what archaeology may be able to contribute to 21st century Experience Society, my answer points to the many great stories that archaeologists can tell about the past and its remains on the one hand and about their own work on the other. Archaeologists will need to get better not only at telling such stories effectively but also at understanding and critically appreciating the overarching meta-stories they evoke. This is not only a matter of practical training but also of intellectual focus. Studying the meta-stories of archaeology is both innovative and timely. For arguably archaeology matters most when its meta-stories matter.

\section{Acknowledgments}

For constructive comments and advice on earlier versions of this paper I am grateful to Gabriel Moshenska, Mark Pluciennik, Tera Pruitt, Neil Silberman and two referees. I should hope that they still do not all agree with everything I wrote.

School of Cultural Sciences, Linnaeus University, Kalmar, Sweden cornelius.holtorf@lnu.se

\section{Notes}

(1) cited from http://www.maropeng.co.za/index.php/maropeng/ (accessed 16 March 2010).

(2) cited from http://www.sagnlandet.dk/MOVE-A-BOULDER.417.0.html (accessed 5 March 2010).

\section{References}

Aronsson, Peter (2004) Historiebruk - att använda det förflutna. Lund: Studentlitteratur.

Ashe, Geoffrey (1992) Atlantis. Lost Lands, Ancient Wisdom. London: Thames and Hudson.

Bowman, Marion (1993) Reinventing the Celts. Religion 23, 147-156.

Burström, Mats (2009) Garbage or Heritage: The Existential Dimension of a Car Cemetery. In: C. Holtorf and A. Piccini (eds) Contemporary Archaeologies. Excavating Now, pp. 131143. Frankfurt/M.: Peter Lang.

Edmonds, Mark (1999) Ancestral Geographies of the Neolithic. Landscapes, monuments and memory. London and New York: Routledge. 
Fagan, Brian (2002) Epilogue. In: B. Little (ed) Public Benefits of Archaeology, pp. 253-60.

Gainesville etc.: University Press of Florida.

Fernández-Armesto, Felipe (2004) So You Think You're Human? Oxford: Oxford University Press.

Flannery, Kent V. (1982) The Golden Marshalltown: A Parable for the Archeology of the 1980s. American Anthropologist, N. S. 84 (2), 265-278.

Högberg, Anders (2006) Kulturmiljöpedagogik och ledarskap. In: B. Riddersporre (ed.) Utbildningsledarskap - nu och i framtiden, pp. 67-102. Lund: Studentlitteratur.

Holtorf, Cornelius (2005) From Stonehenge to Las Vegas. Archaeology as Popular Culture. Lanham: Altamira Press.

Holtorf, Cornelius (2007) Archaeology is a Brand! The Meaning of Archaeology in Contemporary Popular Culture. Oxford: Archaeopress.

Holtorf, Cornelius (2009a) Imagine This: Archaeology in the Experience Society. In: C. Holtorf and A. Piccini (eds) Contemporary Archaeologies. Excavating Now, pp. 47-64. Frankfurt/M.: Peter Lang.

Holtorf, Cornelius (2009b) A European perspective on indigenous and immigrant archaeologies. World Archaeology 41(4): 672-681.

Holtorf, Cornelius (2010) On the Possibility of Time-Travel. Lund Archaeological Review 1516, 2009/10, 31-41.

Jensen, Rolf (1999) The Dream Society. How the coming shift from information to imagination will transform your business. New York: McGraw-Hill.

Landau, Misia (1991) Narratives of Human Evolution: The Hero Story. New Haven: Yale University Press.

Moser, Stephanie (1998) Ancestral Images. The Iconography of Human Origins. Phoenix Mill: Sutton.

Museum of Contemporary Art (1981) Charles Simonds. Chicago: Museum of Contemporary Art.

Pallottino, Massimo (1968) The Meaning of Archaeology. London: Thames and Hudson.

Pearson, Mike and Michael Shanks (2001) Theatre/Archaeology. London and New York: Routledge.

Pine, Joseph, II and James Gilmore (1999) The Experience Economy. Work is Theatre \& Every Business a Stage. Boston, MA: Harvard Business School Press.

Pluciennik, Mark (1999) Archaeological Narratives and Other Ways of Telling. Current Anthropology 40(5), 653-678.

Praetzellis, Adrian and Mary Praetzellis, eds (1998) Archaeologists as Storytellers. Special issue of Historical Archaeology 32 (1), 1-96. (see also the subsequent Forum discussion in 34 (2), 1-24).

Praetzellis, Adrian (2000) Death by Theory. A Tale of Mystery and Archaeological Theory. Lanham: Altamira.

Pruitt, Tera C. (2009) Contextualising Alternative Archaeology. Socio-Politics and Approaches. Archaeological Review from Cambridge 24(1), 55-75. 
Rudebeck, Elisabeth (1996) Heroes and Tragic Figures in the Transition to the Neolithic. Exploring Images of the Human Being in Archaeological Texts. Journal of European Archaeology 4, 55-86.

Schulze, Gerhard (1992) Die Erlebnisgesellschaft. Kultursoziologie der Gegenwart. Frankfurt and New York: Campus.

Silberman, Neil A. (1995) Promised lands and chosen people: the politics and poetics of archaeological narrative. In: P. Kohl and C. Fawcett (eds) Nationalism, Politics, and the Practice of Archaeology, pp. 249-262. Cambridge: Cambridge University Press.

Spector, Janet D. (1993) What This Awl Means: Feminist Archaeology at a Wahpeton Dakota Village. St. Paul: Minnesota Historical Society Press.

Terrell, John (1990) Storytelling and Prehistory. Archaeological Method and Theory 2, 1-29.

Tilden, Freeman (2007) Interpreting Our Heritage [1st ed. 1957]. 4th expanded edition. Chapel Hill: University of North Carolina Press.

Tilley, Christopher (1990) On Modernity and Archaeological Discourse. In: I. Bapty and T. Yates (eds) Archaeology after Structuralism, pp. 128-152. London: Routledge.

White, Hayden (1973) Metahistory: The Historical Imagination in Nineteenth-Century Europe. Baltimore: The Johns Hopkins University Press.

Winkler, Eva-Maria (2006) Kelten heute: Das Keltenbild in der Moderne von der Wissenschaft bis zur Esoterik. Wien: Praesens.

Cornelius Holtorf is Head of Archaeology and Heritage Studies at Linnaeus University, Kalmar, Sweden. His current research interests include contemporary archaeologies, theory of heritage, and the archaeology of time travel. Recent book publications include From Stonehenge to Las Vegas: Archaeology as Popular Culture (2005), Archaeology is a Brand! The Meaning of Archaeology in Contemporary Popular Culture (2007) and Contemporary Archaeologies: Excavating Now (co-edited with A. Piccini, 2009). 